\title{
Dareh Alou thickened tailings management scheme: design considerations
}

\author{
A Roshdieh ATC Williams, Australia \\ K Seddon ATC Williams, Australia \\ M Mohebbi National Iranian Copper Company, Iran \\ K Shakeri Jooyab Nou, Iran \\ M Nosrati Middle East Water and Environment, Iran
}

\begin{abstract}
This paper presents a case study on the design of a thickened tailings storage facility (TSF) for a proposed open pit copper mine at Dareh Alou, Iran.

Dareh Alou mine is a new copper mine owned by National Iranian Copper Company (NICICO). It is located in the Kerman Province of the Islamic Republic of Iran. The nominal production rate is 7 Mtpa for a life-of-mine (LOM) of 25 years. Planning was undertaken for the accommodation of a total of $175 \mathrm{Mt}$ of tailings.

The Dareh Alou mine site is located on a sloping side of a valley that is surrounded by hills, grading up to steep mountainous terrain. Since this is a greenfield project the location of the concentrator was selected in conjunction with the tailings deposition options study. Five concentrator locations with various ore transportation options have been investigated together with the tailings and water management study. The result of the study indicated that the best concentrator plant location was at RL $3050 \mathrm{~m}$ at approximately $2.5 \mathrm{~km}$ from the preferred TSF location.

Various tailings and water management options were evaluated, including high rate, high density/high compression, and paste thickeners. These dewatering options were studied alongside the combinations of various TSF and thickener locations.

The outcome of the options study indicates that if the price of make-up water is not included in the analyses, the preferred option is utilisation of high rate thickeners. However, after inclusion of make-up water at a rate of USD $1 / \mathrm{m}^{3}$, the preferred option would be the utilisation of high density/high compression thickeners. In this case, the distance between the concentrator and the TSF is such that transportation of un-thickened tailings to thickeners located adjacent to the TSF is the most efficient option. Also, thickening the tailings will provide benefits in reducing the embankment construction cost even though relatively large embankments will be required to close off the valley site.
\end{abstract}

Keywords: copper mine, thickened tailings, water saving, trade-off study

\section{$1 \quad$ Introduction}

Dareh Alou mine is a new copper mine owned by National Iranian Copper Company (NICICO) in the Kerman Province of Islamic Republic of Iran.

The surface elevations of the proposed pit are generally between RL 2800 and $2900 \mathrm{~m}$ above sea level. In this study, five concentrator locations with various ore transportation options have been investigated together with the tailings and water management study.

Precipitation at the location of the tailings storage facility (TSF) is at an average of $251 \mathrm{~mm} / \mathrm{a}$. And the amount of pan evaporation is recorded at $1,930 \mathrm{~mm} / \mathrm{a}$. 
Various tailings and water management options were evaluated, including high rate, high density/high compression and paste thickeners. These dewatering options were studied in combination with the various TSF locations and thickeners location options.

\section{Design criteria}

The nominal throughput rate is $7 \mathrm{Mtpa}$, and a mine life of 25 years. The basic parameters are summarised in Table 1.

Table 1 Basic mining parameters

\begin{tabular}{lcc}
\hline Component & Unit & Quantity \\
\hline Life-of-mine (LOM) & Years & 25 \\
Plant throughput & Mtpa & 7 \\
Total tonnage & $\mathrm{Mt}$ & 175 \\
Average throughput rate & $\mathrm{t} / \mathrm{hr}$ & 800 \\
Maximum throughput rate & $\mathrm{t} / \mathrm{hr}$ & 1,034 \\
\hline
\end{tabular}

Tailings testing has been undertaken on samples provided from the metallurgical laboratory and the results are summarised in Table 2.

Table 2 Summary of tailings properties

\begin{tabular}{lccc}
\hline Property & Unit & Value \\
\hline Soil particle density & & $\mathrm{t} / \mathrm{m}^{3}$ & 2.74 \\
Particle size & $\mathrm{D}_{80}$ & $\mu \mathrm{m}$ & 60 \\
& $\mathrm{D}_{50}$ & $\mu \mathrm{m}$ & 23 \\
Initial settled density (ISD) & & $\mathrm{t} / \mathrm{m}^{3}$ & 1.08 \\
In situ average dry density & $\mathrm{t} / \mathrm{m}^{3}$ & 1.50 \\
Liquid limit & $\%$ & 27 \\
Plastic limit & $\%$ & 19 \\
\hline
\end{tabular}

For a total storage capacity of $175 \mathrm{Mt}$ and an adopted end of filling density of $1.5 \mathrm{t} / \mathrm{m}^{3}$, the required design storage capacity is approximately $120 \mathrm{Mm}^{3}$.

Rheological properties of the tailings have been tested with various dosages of flocculent. The results for sheared rheology for a $50 \mathrm{~g} / \mathrm{t}$ dose of flocculent are summarised in Table 3.

Table 3 Summary of sheared rheological properties of tailings

\begin{tabular}{lccccc}
\hline Property & Unit & \multicolumn{4}{c}{$\begin{array}{c}\text { Values (with } \mathbf{5 0} \mathbf{g} / \mathbf{t} \\
\text { dose of flocculent) }\end{array}$} \\
\hline Solids concentration & $\%$ & 40 & 50 & 60 & 66 \\
Yield stress & $\mathrm{Pa}$ & 1 & 5 & 25 & 90 \\
Bingham plastic viscosity & $\mathrm{mPa} . \mathrm{s}$ & 3 & 16 & 57 & 115 \\
\hline
\end{tabular}




\section{Reviewed options}

In this study, a total of 13 potential TSF site options-together with five potential concentrator location options-were initially reviewed. The distance between different TSF site locations and the mine varies from $2 \mathrm{~km}$ to $10.5 \mathrm{~km}$ with different storage efficiencies (capacity of storage/volume of embankment) ranging from 3.25 to 14 (at site 1). The potential concentrator locations range in distance from the mine between $1 \mathrm{~km}$ to $2.5 \mathrm{~km}$. Various ore transportation options from the mine to different concentrator location options, including transportation utilising trucks and conveyor belts, were included in the study. In a combined trade-off study, it was concluded that the combined TSF site 'Location 1' (at a distance of $5 \mathrm{~km}$ from the mine site and $2.5 \mathrm{~km}$ from the preferred concentrator location 'Location $\mathrm{D}^{\prime}$ ) (which in turn is $2 \mathrm{~km}$ from the mine location) would provide the most cost-effective combined system.

The TSF at Site 1 location (central thickened discharge (CTD) scheme option) (Seif et al. 2014) together with the Site $\mathrm{D}$ location for the concentrator are shown in Figure 1.

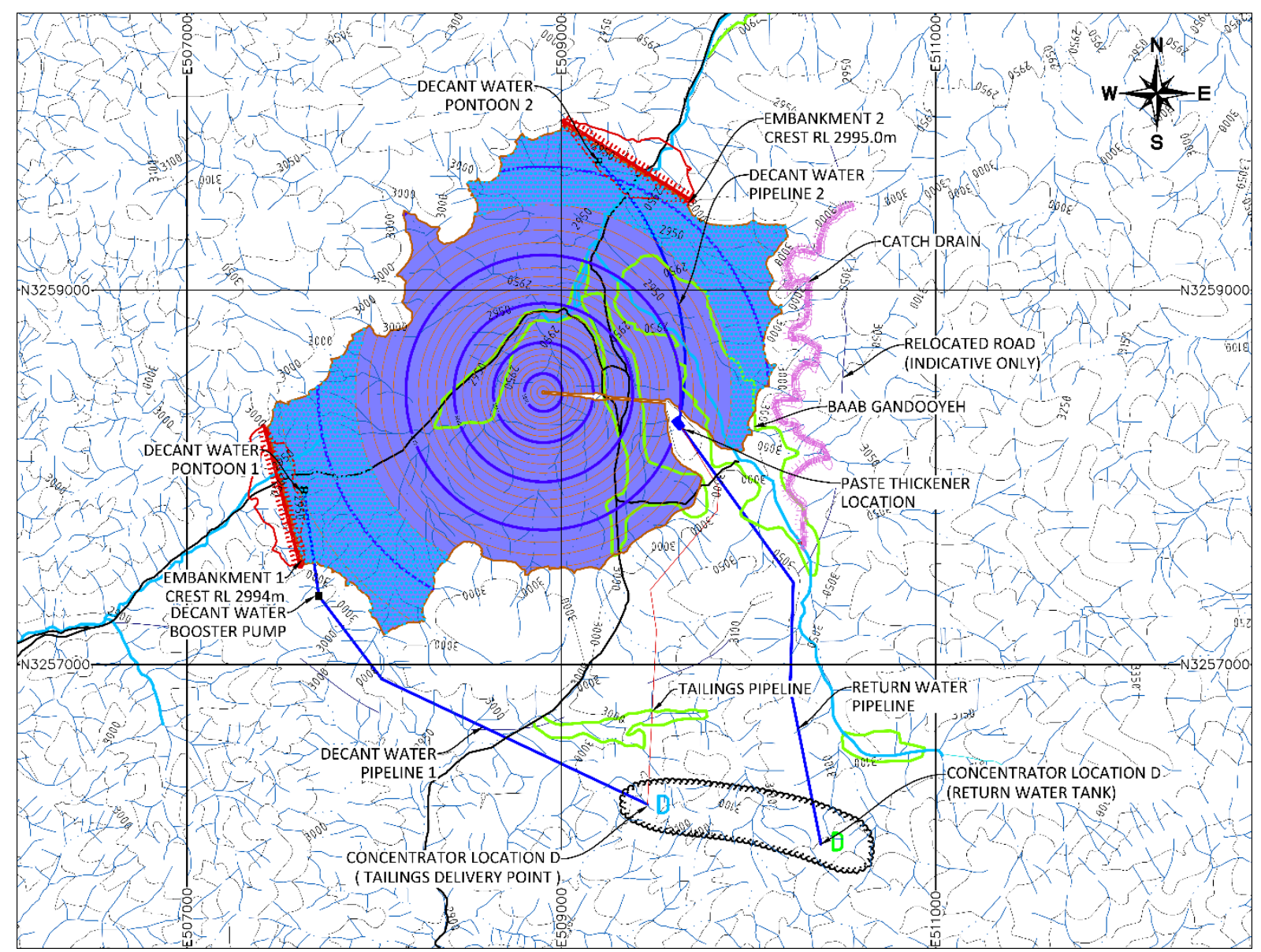

Figure 1 Tailings storage facility at Site 1 location (central thickened discharge (CTD) scheme option) together with Site D location for the concentrator

A key outcome of the comparison was that significant savings were available if the location of the TSF was included in the overall plant location selection studies. According to the plant trade-off study, if the cost of the TSF was not included, the preferred location for the concentrator would have been Location A. In which case even with the adoption of the most cost-effective TSF location option (Site 1) the overall net present value (NPV) of the combined system would have been 30\% (about USD 70M) more expensive compared to the adopted combination (i.e. TSF Site 1 and Concentrator Location D). This is due to the savings achieved in the tailings and water transportation between the concentrator, thickeners and the TSF (Fitton \& Roshdieh 2012). 
In a separate study, the two options of a CTD (Seif et al. 2014) and a down-valley discharge (DVD) scheme, were compared. The conclusion was that the amount of savings due to the utilisation of the CTD option is not likely to be large enough to make the CTD option the preferred one at this site. Thus DVD was selected as the prefered option for this project.

The shape of the adopted DVD scheme in this study, which is shown in Figure 2, is practically $50 \%$ of a full CTD scheme. Another point worth noting is that due to the topography of the region, in both CTD and DVD schemes, relatively large embankments are required on the northeastern and southwestern sides of the TSF. The northeastern side embankment is the main embankment which will have an ultimate height of approximately $90 \mathrm{~m}$. The southwestern embankment is a saddle dam which will not be required at the start-up but will eventually have an utlimate height of approximately $40 \mathrm{~m}$.

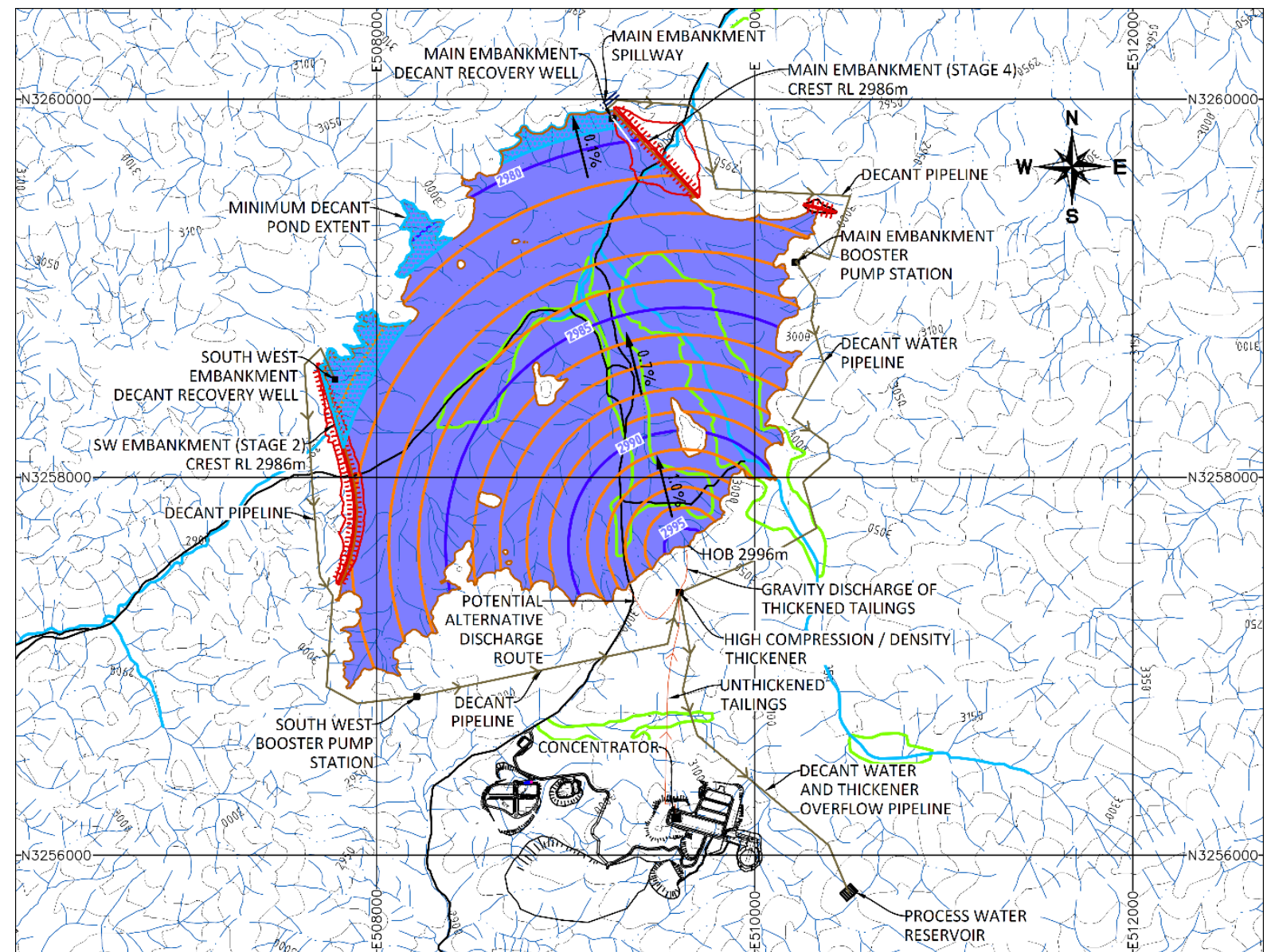

Figure 2 Case 2 down-valley discharge scheme plan at the end of the life-of-mine

As a result, the following DVD cases with various thickening options have been further investigated:

1. Case $1-A$ DVD scheme utilising high rate thickeners (HRT) with underflow solids concentration of $58-60 \%$.

2. Case 2 - A DVD scheme utilising high density/high compression thickeners (HDT/HCT) with underflow solids concentration of $63-64 \%$.

3. Case 3 - A DVD scheme utilising paste thickeners (PT) with underflow solids concentration of $67-68 \%$.

For each of these cases, the assumptions relating to the performance and requirements of each are presented in Table 4. The adopted beach slope profiles for each case are summarised in Table 5. 
Table 4 Assumptions for each case

\begin{tabular}{llcc}
\hline Case & Thickener type & $\begin{array}{c}\text { Underflow solids } \\
\text { concentration }(\%)\end{array}$ & $\begin{array}{c}\text { Flocculent } \\
\text { dosage }(\mathbf{g} / \mathbf{t})\end{array}$ \\
\hline Case 1 & High rate (HRT) & $58-60$ & 25 \\
Case 2 & High density/high compression (HDT/HCT) & $63-64$ & 30 \\
Case 3 & Paste (PT) & $67-68$ & 40 \\
\hline
\end{tabular}

Table 5 Adopted beach slope profile for each case

\begin{tabular}{lcccc}
\hline Case & $\begin{array}{c}\text { Top third } \\
\text { (\%) }\end{array}$ & $\begin{array}{c}\text { Middle third } \\
\text { (\%) }\end{array}$ & $\begin{array}{c}\text { Bottom third } \\
\text { (\%) }\end{array}$ & $\begin{array}{c}\text { Runout } \\
\text { (\%) }\end{array}$ \\
\hline Case 1 & 0.65 & 0.5 & 0.4 & 0.1 \\
Case 2 & 1.0 & 0.7 & 0.5 & 0.1 \\
Case 3 & 1.45 & 1.1 & 0.8 & 0.1 \\
\hline
\end{tabular}

These three cases are discussed in more detail in the following sections.

\section{Components of each case}

\subsection{Case 1 - Down-valley discharge in conjunction with high rate thickeners}

In this case, unthickened tailings are delivered to the remote location (with respect to the Plant Site) of the HRT (i.e. adjacent to the TSF). The underflow, at 58 to $60 \%$ solids concentration (w/w), will then be deposited via a DVD scheme by means of single point discharge.

The tailings are transferred from the concentrator at RL $3080 \mathrm{~m}$ to the high rate thickeners at $\mathrm{RL} 3040 \mathrm{~m}$ via a $1.4 \mathrm{~km}$ long, high-density polyethylene (HDPE), PN10 pipe with a nominal diameter of $900 \mathrm{~mm}$. The thickeners are taken to be two units each with a diameter of $28 \mathrm{~m}$. The thickeners sizes were provided by the thickener suppliers.

The underflow from the thickeners will be transferred to the head of beach via a $500 \mathrm{~mm}$ wide concrete channel or a $200 \mathrm{~m}$ long mining hose with an internal diameter of $280 \mathrm{~mm}$. The natural available slope is approximately $20 \%$ which will generate a flow velocity in excess of $5 \mathrm{~m} / \mathrm{sec}$ which is above the transition velocity. In this case a turbulent flow regime will be maintained. The rate of wear at this velocity would be high and regular repair and replacement would be necessary. However, due to the short length of the line the cost of repairs and replacement are not significant.

The return water (including decant water and catchment runoff) is transferred from the return water tank at $\mathrm{RL} 3040 \mathrm{~m}$ to the process water reservoir at RL $3230 \mathrm{~m}$ via a $711 \mathrm{~mm}$ steel pipe with a total length of $2 \mathrm{~km}$, requiring a $1.9 \mathrm{MW}$ pump station.

The decant water system in this case comprises of two main parts; a $230 \mathrm{~kW}$ pump station at the main embankment to transfer the decant and runoff water via a $2.3 \mathrm{~km}$ HDPE PN16 pipe with NS of $315 \mathrm{~mm}$ to the booster pump station at RL $3000 \mathrm{~m}$. It should be noted that the rating of the pipeline can be reduced at higher elevations at later stages of the design; and a $120 \mathrm{~kW}$ booster pump station at RL $3000 \mathrm{~m}$ to transfer water to the return water tank adjacent to the thickeners, via a $2.5 \mathrm{~km}$ HDPE PN10 pipe with NS of $315 \mathrm{~mm}$. Figure 3 shows the flow diagram for Case 1. The plan is very similar to Figure 2 except that the head of beach (HoB) and the embankments crest elevation are slightly higher. 


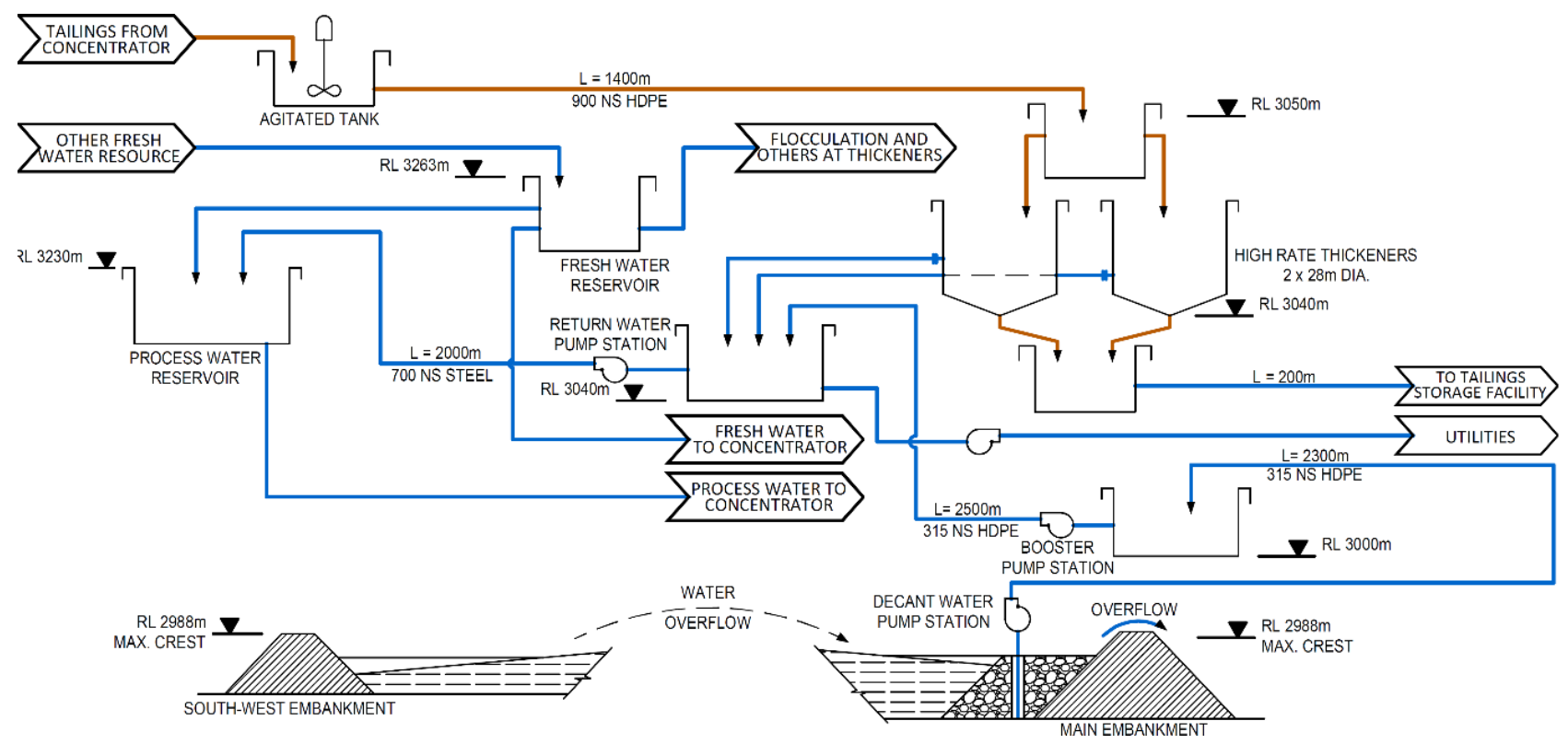

Figure 3 Case 1 (down-valley discharge and high rate thickeners) flow diagram

In this case the embankment crests are at $2988 \mathrm{~m} \mathrm{RL}$ with a total volume of earthworks of $5.7 \mathrm{Mm}^{3}$. It has been assumed that the construction of the embankments will take place in four stages.

\subsection{Case 2 - Down-valley discharge and high density/high compression thickeners}

In Case 2, unthickened tailings are delivered to the remote location of the HDT/HCT (adjacent to the TSF). The underflow will then be deposited in a DVD scheme from a single discharge point.

The tailings transportation system from the concentrator to the thickeners is similar to that of Case 1 . The underflow tailings transportation line from the thickeners to the head of beach and the return water system are also similar to Case 1.

The thickeners in this case, as sized by the supplier are to be two units each with a diameter of $28 \mathrm{~m}$. This is the same as the HRT units, but details including depth, rake capacity etc. vary.

The decant water system, comprises of two main parts; a $170 \mathrm{~kW}$ pump station at the main embankment to transfer decant and runoff water via a $2.3 \mathrm{~km}$ HDPE PN16 pipe with NS of $315 \mathrm{~mm}$ to the booster pump station at RL $3000 \mathrm{~m}$; and a $110 \mathrm{~kW}$ booster pump station at RL $3000 \mathrm{~m}$ to transfer water to the return water tank adjacent to the thickeners, via a $2.5 \mathrm{~km}$ HDPE PN10 pipe with NS of $280 \mathrm{~mm}$.

A plan of Case 2 is presented in Figure 2 and the flow diagram is shown in Figure 4.

In this case the modified beach profile results in embankment crests at RL $2986 \mathrm{~m}$ with a total volume of earthwork of $5.2 \mathrm{Mm}^{3}$. This is only a marginal saving compared to Case 1 . It has been assumed that the construction of the embankments will take place in four stages. 


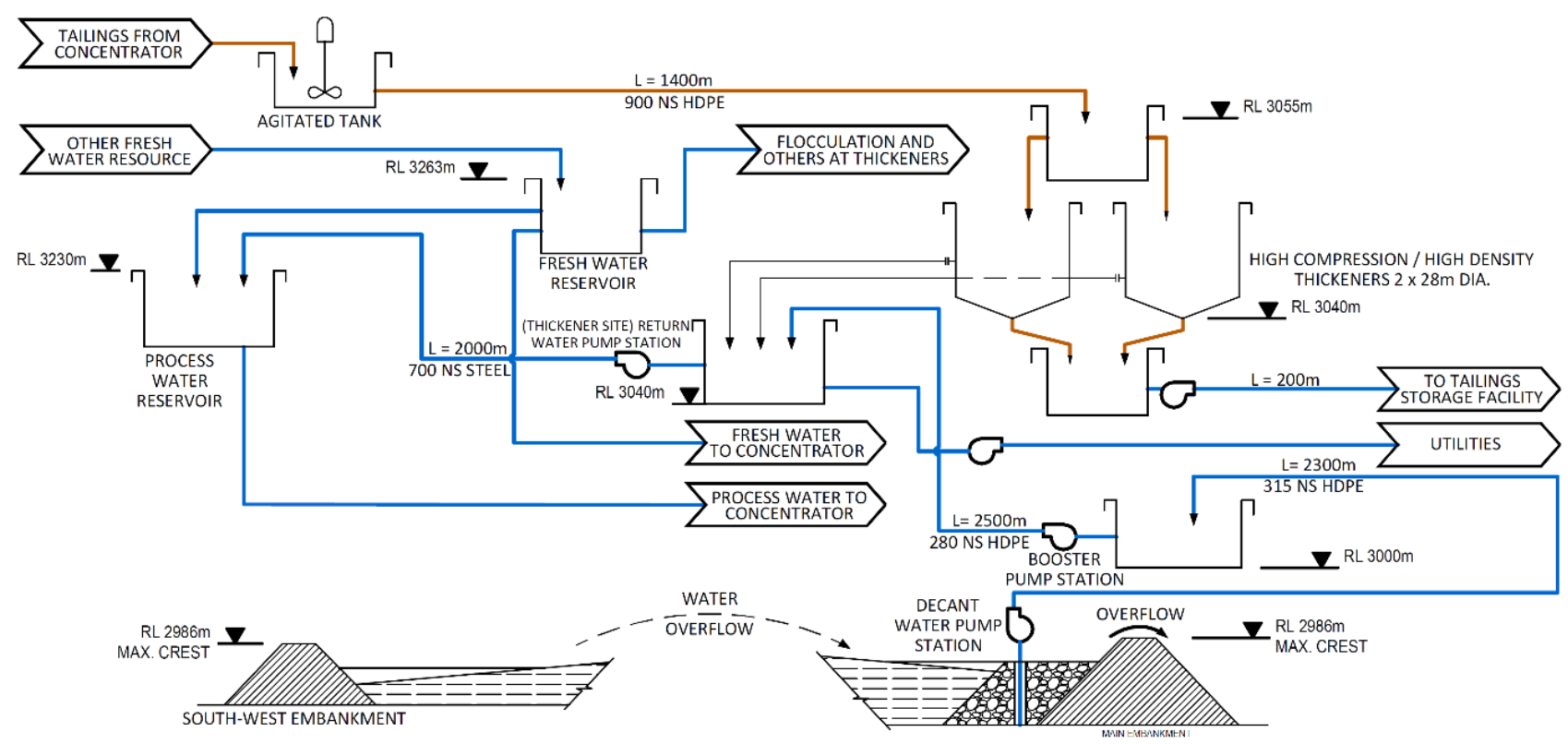

Figure 4 Case 2 (down-valley discharge and high density/high compression thickeners) flow diagram

\subsection{Case 3 - Down-valley discharge and paste thickeners}

In Case 3, unthickened tailings are delivered to the remote location of PT (adjacent to the TSF). The underflow will then be deposited from a single discharge point.

The tailings transportation system from the concentrator to the thickeners is similar to that of Cases 1 and 2 . The underflow tailings transportation line from the thickeners to the head of beach, and the return water system, are also similar to Cases 1 and 2.

The thickeners in this case, as sized by the supplier are to be two units each with a diameter of $28 \mathrm{~m}$, but again with different details.

The decant water system comprises of two main parts; a $160 \mathrm{~kW}$ pump station at the main embankment to transfer decant and runoff water via a $2.3 \mathrm{~km}$ long HDPE PN16 pipe with NS of $315 \mathrm{~mm}$ to the booster pump station at RL $3000 \mathrm{~m}$; and a $100 \mathrm{~kW}$ booster pump station at RL $3000 \mathrm{~m}$ to transfer water to the return water tank adjacent to the thickeners, via a $2.5 \mathrm{~km}$ HDPE PN10 pipe with NS of $280 \mathrm{~mm}$. Figure 5 represents the flow diagram for Case 3. The plan is very similar to Figure 2 except for the fact that the HoB and the embankments crest elevation are slightly lower.

In this case the beach profile results in the embankment crests at $2985 \mathrm{~m} \mathrm{RL}$ with the total volume of earthworks of $5.0 \mathrm{Mm}^{3}$. Again, this is only a moderate saving compared to previous options. It has been assumed that the construction of the embankments will take place in four stages. 


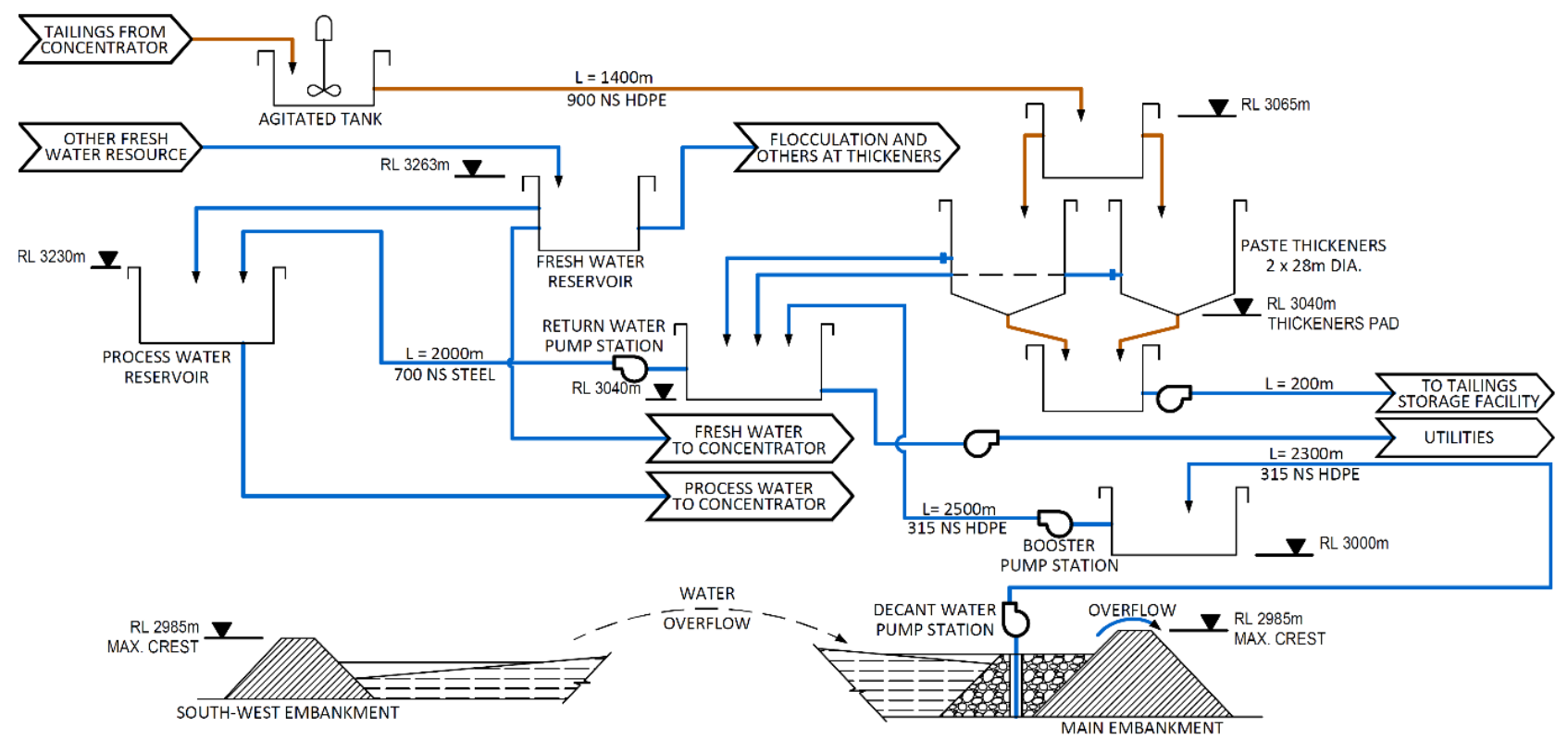

Figure 5 Case 3 (down-valley discharge and paste thickeners) flow diagram

\section{$5 \quad$ Water management}

The important difference between the cases in this study the water recovery. This is controlled by the amount of water that remains in the tailings discharge to the TSF and hence the amount of bleed water. The bleed water in the TSF will be exposed to evaporation, thus it is expected that part of the bleed water is evaporated and lost before it can be returned. The outcomes of the water management study are briefly presented in Tables 6 and 7.

Table 6 Adopted return water capacity and bleed water (excluding runoff) calculations

\begin{tabular}{lccc}
\hline Case & $\begin{array}{c}\text { Adopted decant } \\
\text { water pump capacity } \\
\left(\mathbf{m}^{3} / \mathrm{hr}\right)\end{array}$ & $\begin{array}{c}\text { Theoretical } \\
\text { bleed water } \\
\left(\mathbf{M m}^{3} / \mathbf{a}\right)\end{array}$ & $\begin{array}{c}\text { Actual bleed water } \\
\text { (after evaporation) } \\
\left(\mathbf{M m}^{3} / \mathrm{a}\right)\end{array}$ \\
\hline Case 1 & 417 & 0.740 & 0.507 \\
Case 2 & 333 & 0.184 & 0.033 \\
Case 3 & 313 & 0 & 0 \\
\hline
\end{tabular}

Table 7 Water management study outcomes

\begin{tabular}{lccc}
\hline Case & $\begin{array}{c}\text { Water recovered } \\
\text { by thickening } \\
\left(\mathbf{M m}^{3} / \mathbf{a}\right)\end{array}$ & $\begin{array}{c}\text { Average returned } \\
\text { water from TSF } \\
\left(\mathbf{M m}^{3} / \mathbf{a}\right)\end{array}$ & $\begin{array}{c}\text { Total water } \\
\text { recovery } \\
\mathbf{( \% )}\end{array}$ \\
\hline Case 1 & 12.9 & 1.65 & 81 \\
Case 2 & 13.9 & 1.21 & 84 \\
Case 3 & 14.6 & 1.16 & 88 \\
\hline
\end{tabular}


Based on the outcomes in Tables 6 and 7 and the expected performance of the thickeners, the total required make-up (fresh) water has been estimated for each case, and is presented in Table 8 . This will be required to be supplied from external sources, which are limited and have conflicting demands.

Table 8 Required freshwater from external sources

\begin{tabular}{lcc}
\hline Case & $\begin{array}{c}\text { Average total } \\
\text { required freshwater } \\
\text { from external sources } \\
\left(\mathbf{M m}^{3} / \mathrm{a}\right)\end{array}$ & $\begin{array}{c}\text { Maximum required } \\
\text { freshwater from } \\
\text { external sources } \\
\left(\mathbf{m}^{3} / \mathbf{h r}\right)\end{array}$ \\
\hline Case 1 & 5.5 & 950 \\
Case 2 & 4.5 & 850 \\
Case 3 & 3.9 & 710 \\
\hline
\end{tabular}

Even though the Dareh Alou mine is located in a dry province, there are several streams flowing in the vicinity of the mine and the TSF. These natural streams may be available as external sources of freshwater; however, the mine has to share this existing water sources with the local farmers. In terms of community relations, and the overall social licence to operate, it has been necessary for the design to be able to demonstrate an approach that reaches as sensible minimum on demand for external make-up water.

As a supplementary option, a water supply dam (Safa Roud Water dam) is currently being constructed to supply water for residential and farming purposes by the local water authorities at a location approximately $20 \mathrm{~km}$ from the mine, with a main water transportation pipeline passing close to the mine. Water from Safa Roud dam is planned to be supplied to Dareh Alou mine for the make-up of any water deficit.

\section{Cost estimation and analysis}

The main unit rates used for the calculation of the capital expenditure (CAPEX) in this study are presented in Table 9.

Table 9 Main rates for capital expenditure

\begin{tabular}{lcc}
\hline Item & Unit & $\begin{array}{c}\text { Unit rate } \\
\text { (USD/unit) }\end{array}$ \\
\hline Embankment construction & $\mathrm{m}^{3}$ & 10 \\
High rate thickener and associated facilities & Unit & $3.2 \mathrm{M}$ \\
High density/high compression thickener and associated facilities & Unit & $4.8 \mathrm{M}$ \\
Paste thickener and associated facilities & Unit & $8.2 \mathrm{M}$ \\
\hline
\end{tabular}

The operational expenditure (OPEX), are the costs associated with maintaining and operating the system. The key rates and figures which are used for the calculation of the operations costs in this study are presented in Table 10. 
Table 10 Main rates and figures for operational expenditure

\begin{tabular}{lcc}
\hline Item & Unit & $\begin{array}{c}\text { Unit rate } \\
\text { (USD/unit) }\end{array}$ \\
\hline Rate of return & $\%$ & 8 \\
Power costs & $\mathrm{kWhr}$ & 0.1 \\
Price of water & $\mathrm{m}^{3}$ & 1 \\
Flocculent & $\mathrm{kg}$ & 5 \\
$\begin{array}{l}\text { Maintenance cost of pipelines } \\
\text { Maintenance cost of pumps and } \\
\text { other equipment }\end{array}$ & \% of CAPEXX & 1 \\
\hline
\end{tabular}

Based on the information in Tables 9 and 10, NPV for the cost of each of the cases have been estimated and are presented in Table 11. The NPVs are estimated for two main options; without including the price of freshwater; and including the price of freshwater (at USD $1 / \mathrm{m}^{3}$ ).

Table 11 Net present value (NPV) for costs of various cases

\begin{tabular}{lccccc}
\hline Case & $\begin{array}{c}\text { Initial } \\
\text { (start-up) } \\
\text { costs (USD M) }\end{array}$ & $\begin{array}{c}\text { Total CAPEX } \\
\text { (USD M) }\end{array}$ & $\begin{array}{c}\text { OPEX } \\
\text { (USD M) }\end{array}$ & $\begin{array}{c}\text { NPV (before } \\
\text { adding the price } \\
\text { of water (USD M) }\end{array}$ & $\begin{array}{c}\text { NPV (after adding } \\
\text { the price of } \\
\text { water (USD M) }\end{array}$ \\
\hline Case 1 & 42 & 72 & 2.42 & 79 & 133 \\
Case 2 & 43 & 70 & 2.83 & 83 & 131 \\
Case 3 & 48 & 75 & 3.43 & 95 & 136 \\
\hline
\end{tabular}

CAPEX - capital expenditure; OPEX - operational expenditure

These outcomes are also shown graphically in Figure 6.

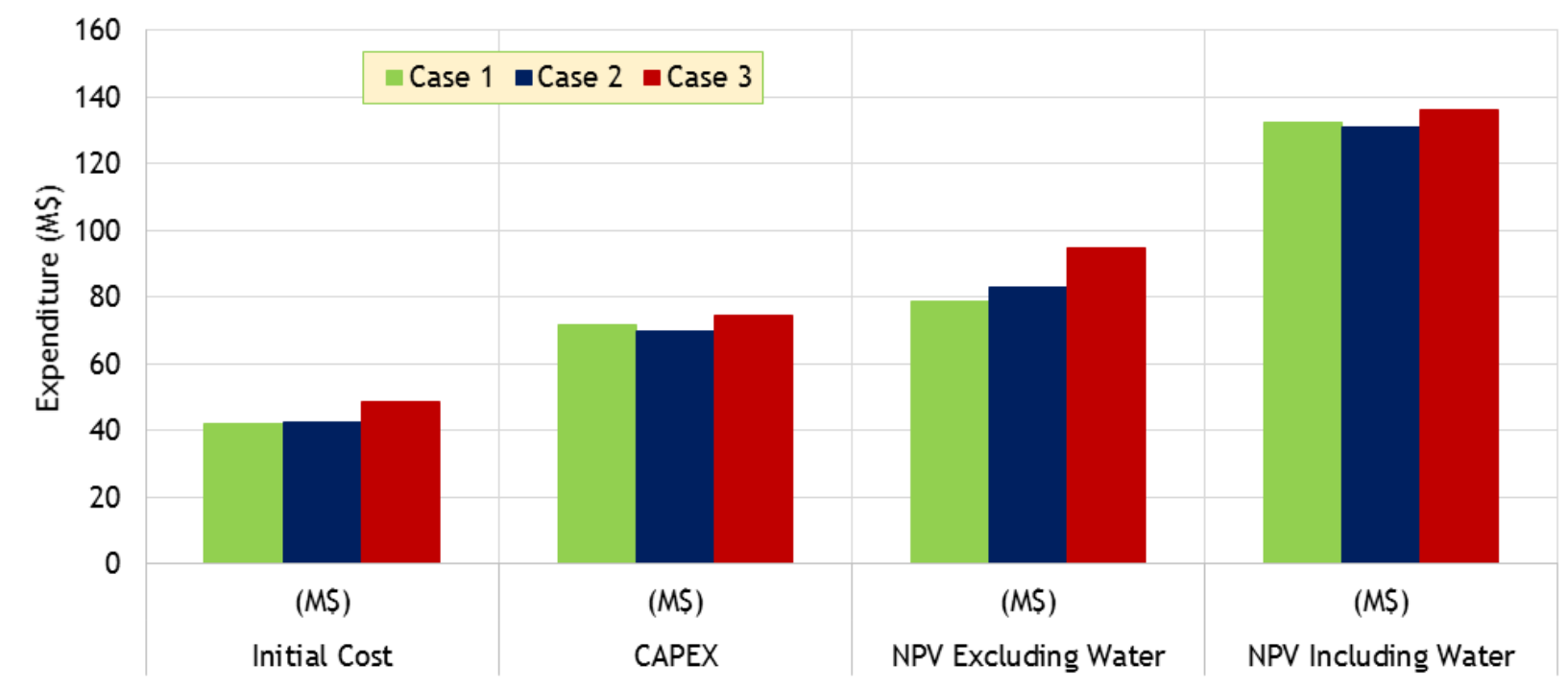

Figure 6 Costs of various cases

The results indicate that the difference in NPV between the three options is relatively small. However, as expected, the impact of the price of water in this study is substantial. A sensitivity analysis was undertaken to further investigate the influence of the price of make-up water, and the results are presented in Figure 7. 
This indicates that higher levels of thickening (and improved site water usage) can be directly related to the cost of make-up water.

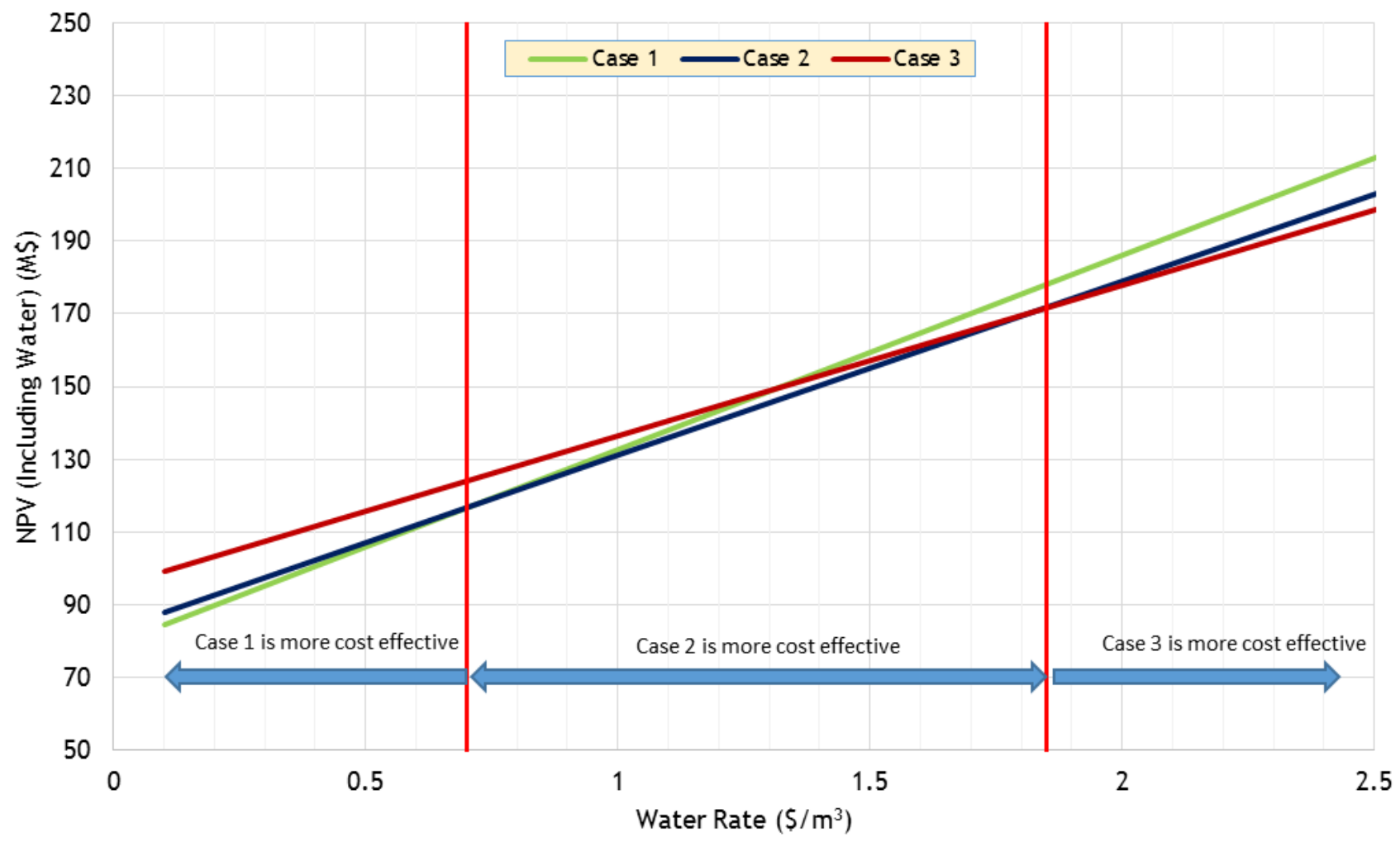

Figure 7 Sensitivity analysis on the price of water

\section{$7 \quad$ Discussions and summary}

Based on the findings in Table 11 and Figures 6 and 7, the differences in costs between various cases are not great. However, these results can be regarded as guidelines for comparison purposes.

Based on these findings, Case 1 has the lowest initial cost and lowest NPV if the price of water supply is excluded. On the other hand, Case 2 has the comparative lowest CAPEX and NPV if the price of water $\left(\right.$ at USD $1 / \mathrm{m}^{3}$ ) is included. The overall cost is sensitive to the price of water. Based on Figure 7, if the unit price of water is less than USD $0.7 / \mathrm{m}^{3}$, Case 1 would be the most economically attractive case. For a water price between USD $0.7 / \mathrm{m}^{3}$ to USD $1.85 / \mathrm{m}^{3}$, Case 2 would be the most attractive case. Case 3 becomes the most attractive option for water prices higher than USD $1.85 / \mathrm{m}^{3}$.

\section{Conclusion and recommendation}

Based on the outcomes of the study, Case 2 has been recommended as the preferred option for tailings and water management at the Dareh Alou project:

- The price of water at Dareh Alou it is not expected to higher than USD $1.5 / \mathrm{m}^{3}$.

- Given that the cost difference between options is low, failure to achieve the full design thickener underflow and beach profile is not considered to be a critical consideration.

- However, if the price of water increases in the future, it will make Case 2 an even a better choice compared to Case 1.

As a final note, the study has shown that in this instance the concentrator location was a significant factor in optimising the overall mine and tailings disposal scheme layout and can potentially save the client significant cost. 


\section{Acknowledgements}

The authors wish to express their gratitude to Mr Khoshniaz and Mr Seif, previous heads of the Integrated Water Master Plan (IWMP) office at NICICO at various stages of the project, for their support and cooperation. Also, the managers and engineers at both ATC Williams and Middle East Water and Environment should be acknowledged for their technical support.

\section{References}

Fitton, TG \& Roshdieh, A 2012, The Impact of Slurry Rheology on Tailings Transport and Disposal Options - Four Cases Studies, presented at the IIR's 2nd Slurry Pipelines Conference, 20-21 November 2012, Perth, Australia.

Seif, HR, Roshdieh, A \& Zaker, H 2014, 'Optimisation of tailings and water management schemes in Taft and Dareh Alou copper mines', Proceedings of the International Symposium on Dams in a Global Environmental Challenges, International Commission on Large Dams, Paris. 